\title{
Comparison of multi-locus enzyme and protein gel electrophoresis in the discrimination of five Fusarium species isolated from Egyptian cottons
}

\author{
Ibrahim N. Aly ${ }^{1}$, Mohmed A. Abdel-Sattar ${ }^{1}$, \\ Kamel A. Abd-Elsalam ${ }^{2,3^{*}}$ Mohmed S. Khalil ${ }^{2}$ and Joseph A. Verreet ${ }^{3}$ \\ ${ }^{1}$ Suez Canal University, Faculty of Agriculture, Ismailia, Egypt. \\ ${ }^{2}$ Agricultural Research Center, Plant Pathology Research Institute, Giza, Egypt. \\ ${ }^{3}$ Christian Albrechts Universität zu Kiel, Institut für Phytopathologie, Kiel, Germany.
}

Accepetd 21 May 2003

\begin{abstract}
Electrophoretic studies of multilocus-enzymes (MLEE) and whole-cell protein (SDS-PAGE) were carried out in order to evaluate the parity between different methods for the characterization of five Fusarium species recovered from cotton-growing areas in Egypt by numerical taxonomy methods. The obtained data revealed that SDS-PAGE and esterase isozymes are more efficient in grouping isolates in their respective species while peroxidase and malate dehydrogenase isozyme has much limited resolution in organizing all isolates in their respective species-specific clusters. A low correlations was detected between geographical origin of isolates and genetic diversity. Results indicate that the estimated inter-specific variation may be more pronounced with protein markers than with isoyzmes when the two approaches are applied to the same populations. The level of genetic variability detected within and between Fusarium spp. accessions with protein and esterase isoyzmes analysis suggests that it is a reliable, efficient, and effective marker technology for determining genetic relationships in Fusarium genus.
\end{abstract}

Key words: Cotton, Fusarium, Isozymes, polyacrylamide gel electrophoresis.

\section{INTRODUCTION}

Numerous biochemical and molecular markers are available for the clarification and delineation of fungal taxa. Isozymes studies have proven useful for the identification of fungal cultures at species (Bonde et al., 1991; Petrunak and Christ 1992) or subspecies level (Julian and Lucas 1990; Damaj et al., 1993).

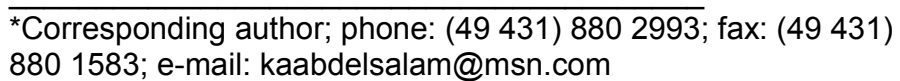

Abbreviations: MLEE, multilocus-enzymes electrophoresis; SDS-PAGE, sodium dodcyle sulphate polyacrylamide gel electoophoresis; UPGMA, unweighted pair group method using arithmetic.
Electrophoretic analysis of whole cell proteins by onedimensional protein patterns provides a rough measure of the number and physicochemical properties of gene products. One-dimensional polyacrylamide gel electrophoresis of proteins has been used extensively for identification and classification at the strain and species level (Snider, 1973). However, as seen with other methods based on the analysis of gene products, effects such as the influence of the composition of growth media on the banding pattern and superposition of proteins cause problems in the interpretation of data. Highly standardized conditions and computerized comparison of the electropherograms are necessary to obtain reproducibility of results obtained from different laboratories. Isozymes are also useful tools for 
differentiating fungal taxa at the specific and intra-specific level. Bosland and Williams (1987) were able to define isozyme electrophoretic types, which could be used to differentiate Fusarium species and four F. oxysporum formae specials. The role of Fusarium spp. as a pathogen of cotton seedlings, and other crops is well known. Although Johnson and Doyle (1986) reported that Fusarium spp. were not important pathogens in cotton seedling disease complex, they are often the most frequently isolated fungi. Isolates of Fusarium spp. have previously been shown to be pathogenic on seedling cotton (Colyer, 1988; Aly et al., 1996; Zhang et al., 1996). The objectives of the present study were to differentiate the five closely related Fusarium species $(F$. oxysporum, $F$. moniliforme, $F$. solani, $F$. avenaceum and $F$. chlamydosporum) through two main approaches: isozyme analysis and protein gel electrophoresis.

\section{MATERIALS AND METHODS}

\section{Fungal cultures}

Forty-six isolates of Fusarium spp. from diverse geographical origins were used. Mycelium production was carried out by culturing the fungi in $100 \mathrm{ml}$ of potato dextrose broth in 500-ml Erlenmeyer flasks and incubating them at $28^{\circ} \mathrm{C}$ for 6 days. Mycelial mats were then filtered under vacuum on a Büchner funnel, rinsed twice with distilled water and blotted dry. Mycelium to be used for isozyme and protein analyses was freeze-dried and stored at $-20^{\circ} \mathrm{C}$.

\section{Preparation of protein extracts}

Soluble proteins were extracted by grinding $100 \mathrm{mg}$ freeze-dried mycelium with pestle and mortar in liquid nitrogen and $5 \mathrm{ml}$ buffer solution $(0.1 \mathrm{M}$ Tris- $\mathrm{HCl}, \mathrm{pH} 6.8)$. The mixture was centrifuged for 20 $\min$ at $17.000 \mathrm{rpm}$ and the supernatant collected. The protein content in supernatant was estimated according to the method of Bradford (1976) with bovine serum albumin as standard protein. Protein content was adjusted to $2 \mathrm{mg} / \mathrm{ml}$ per sample.

\section{Standard conditions for SDS polyacrylamide gel electoophoresis (protein fingerprinting)}

SDS-PAGE was performed by the method described by Laemmli (1970), and modified according to Hames (1995). Proteins were analyzed on 1.5-mm thick and $15-\mathrm{cm}$ long gels run in a dual vertical slab unit (Hoefer Scientific Instruments, San Francisco, CA, USA, Model SE 600 Series Hoefer ${ }^{\circledR}$ Pharmacia Biotech). From each sample, $25 \mu \mathrm{l}$ of extract was loaded on a polyacrylamide gel. The separation gel $(10 \%)$ and staking gel $(3.5 \%)$ were prepared from an acrylamide monomer solution (Roth, Karlsruhe, Germany). Electrophoresis was carried out at a constant current of $35 \mathrm{~mA}$ through the stacking gel, and at $90 \mathrm{~mA}$ through the separation gel at room temperature. After electrophoresis, the gels were stained by silver nitrate (Rabilloud et al., 1988).

\section{Sample preparation for isozymes electrophoresis}

One-hundred milligrams of freeze-dried mycelium were homogenized by grinding in liquid nitrogen with a mortar and pestle, and suspended in $1.5 \mathrm{ml}$ of extraction buffer $(10 \mathrm{mM}$ Tris- $\mathrm{HCl}, 1$
$\mathrm{mM}$ EDTA, $0.1 \mathrm{mM}$ ascorbic acid, $\mathrm{pH} 7$ ). Extracts were chilled in an ice bath for $1-3 \mathrm{~h}$ and centrifuged at $18.000 \mathrm{rpm}$ for $30 \mathrm{~min}$ at $4{ }^{\circ} \mathrm{C}$. The supernatant was collected, divided into $100-\mu$ l aliquots, stored at $-80^{\circ} \mathrm{C}$, and used within 6 months.

\section{Multilocus-enzymes electrophoresis}

Isozymes electrophoresis was performed in vertical polyacrylamide gels with a discontinous buffer system as described by Iglesias et al. (1974). The following enzyme systems were screened: esterase (EST, 3.1.1.1), malate dehydrogenase (MDH, 1.1.1.37), and peroxidase (POX, EC 1.11.1.7). The staining protocols used are described by Gall et al. (1995).

\section{Computing numerical data}

Dendrograms for the different MLEE systems and SDS-PAGE were generated by using the one-dimensional software analysis (Advanced American Biotechnology and Imaging, Fullerton CA 92831, USA). For cluster analysis of protein and isozymes banding patterns, the unweighted pair group method using average linkages (UPGMA) was used (Vauterin and Vauterin, 1992)

\section{RESULTS}

\section{SDS-PAGE analysis}

Cluster analysis of the protein markers data placed the Fusarium species into main groups (Figure 1), according to their previous species assignment. The genetic similarity between Fusarium spp. isolates ranged from 21 to $54 \%$ for inter-specific and 62 to $97 \%$ for intra-specific comparisons. The application of UPGMA clustering produced two large clusters within the population with a branched-off at genetic similarity of $21.46 \%$, each consisting of several subclusters (phenons).

The first main cluster included all $F$. oxysporum, all $F$. moniliforme and $F$. chlamydosporum isolates. Within this cluster, $\mathrm{Fa} 1$ and $\mathrm{Fa} 2$ have a genetic similarity of GS $=95.98 \%$. Isolates Fo24 and Fo25 also showed very high genetic similarity of $99.22 \%$. The second cluster consists of $F$. solani isolates at the genetic similarity of $31.37 \%$. Here, isolates Fs3 and Fs4 showed very high genetic similarity of $97.26 \%$. Clustering analysis indicates that the 46 Fusarium spp. isolates can be assigned to six protein types. There was low correlation between clustering in the protein dendrogram and geographic origin. These results suggested that protein profiles data clearly separated Fusarium spp. isolates.

\section{Isozymes analysis}

The activity and resolution of three enzyme-staining procedures for Fusarium spp. were tested. Poor resolution was observed for the enzymes peroxidase and malate dehydrogenase (data not shown), while esterase 


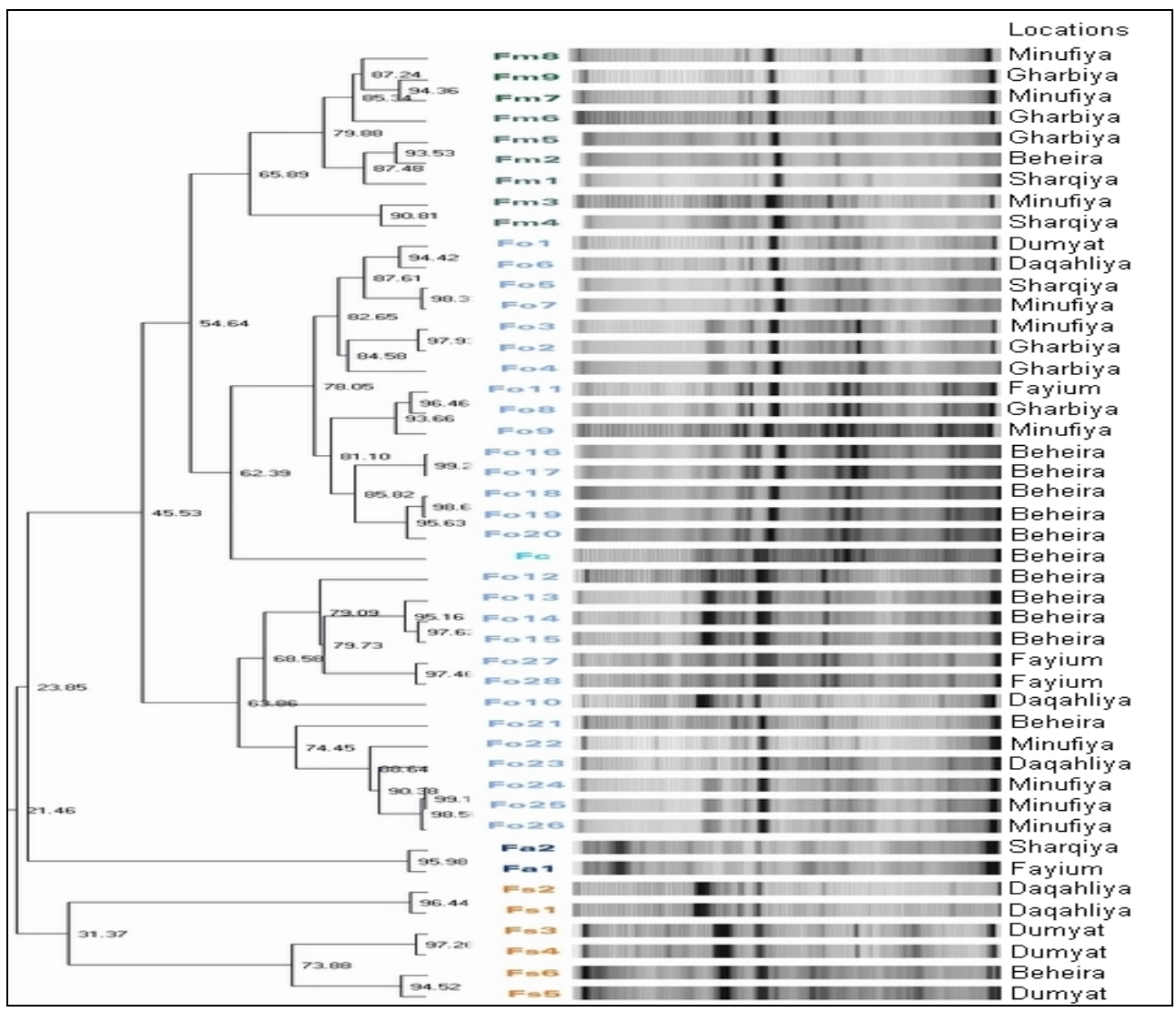

Figure 1. Dendrogram derived from the UPGMA linkage of correlation coefficients between SDS-PAGE profiles from five Fusarium spp. isolates. The levels of linkage representing the Pearson product-moment correlation coefficient $(r)$ are expressed as percentages for convenience. The banding profiles against each branch represent normalized and background-subtracted digitized gel strips processed in ABB program.

enzyme showed strong activity and acceptable resolution.

Esterase banding patterns obtained by native PAGE were concatenated and analyzed as a composite by $A A B$ software. The normalization setting used were as follows: a resolution of 500 points, a smoothing factor of 3 , and background subtraction by the rolling-disk method with intensity setting of 12 , and the patterns were clustered by unweighted pair group method of arithmetic average.

The obtained dendrogram (Figure 2) depicts that all isolates belong to two distinct groups (similarity are above $20 \%$ ). The genetic similarity between Fusarium spp. isolates ranged from 29 to $54 \%$ for inter-specific and 60 to $97 \%$ for intra-specific comparisons.

The first main cluster included all $F$. oxysporum isolates, $F$. moniliforme and $F$. chlamydosporum isolates, constituted one cluster branched from the first main cluster at level of 61.01 genetic similarity. Here, Fa1 and Fa2 have a genetic similarity of $75.59 \%$. Isolates Fo12 and Fo13 also showed very high genetic similarity of $99.46 \%$. Both were collected from Beheira governorate and could be identical. The second main cluster consist of $F$. solani isolates at the genetic similarity of $73.93 \%$. Isolates Fs1 and Fs2 showed very high genetic similarity of $97.77 \%$. Within the cluster of $F$. oxysporum, low correlation between the geographic origin of the isolates and their esterase patterns were observed. At the $65 \%$ genetic similarity, the $28 \mathrm{~F}$. oxysporum isolates could be divided into four subgroups. Some of the F. solani isolates that had been collected from the same locations also showed a tendency to cluster. Only one isolate, Fm8, could not be classified by esterase analysis.

\section{DISCUSSION}

Biochemical and molecular markers are being increasingly used to characterize fungal plant pathogen populations. They are versatile and highly informative tools for fungal pathogen identification and diagnosis (Majer et al., 1996) and for populations genetics studies (McDonald and McDermott, 1993; McDonald et al., 1999). They can be used to evaluate levels of genetic diversity and phenotypic relationships within and between species, and to identify particular races and pathotypes (Brown, 1996). The electrophoretic separation of protein, including isozymes, is a useful tool for differentiating fungal taxa. Bosland and Williams (1987) have used 


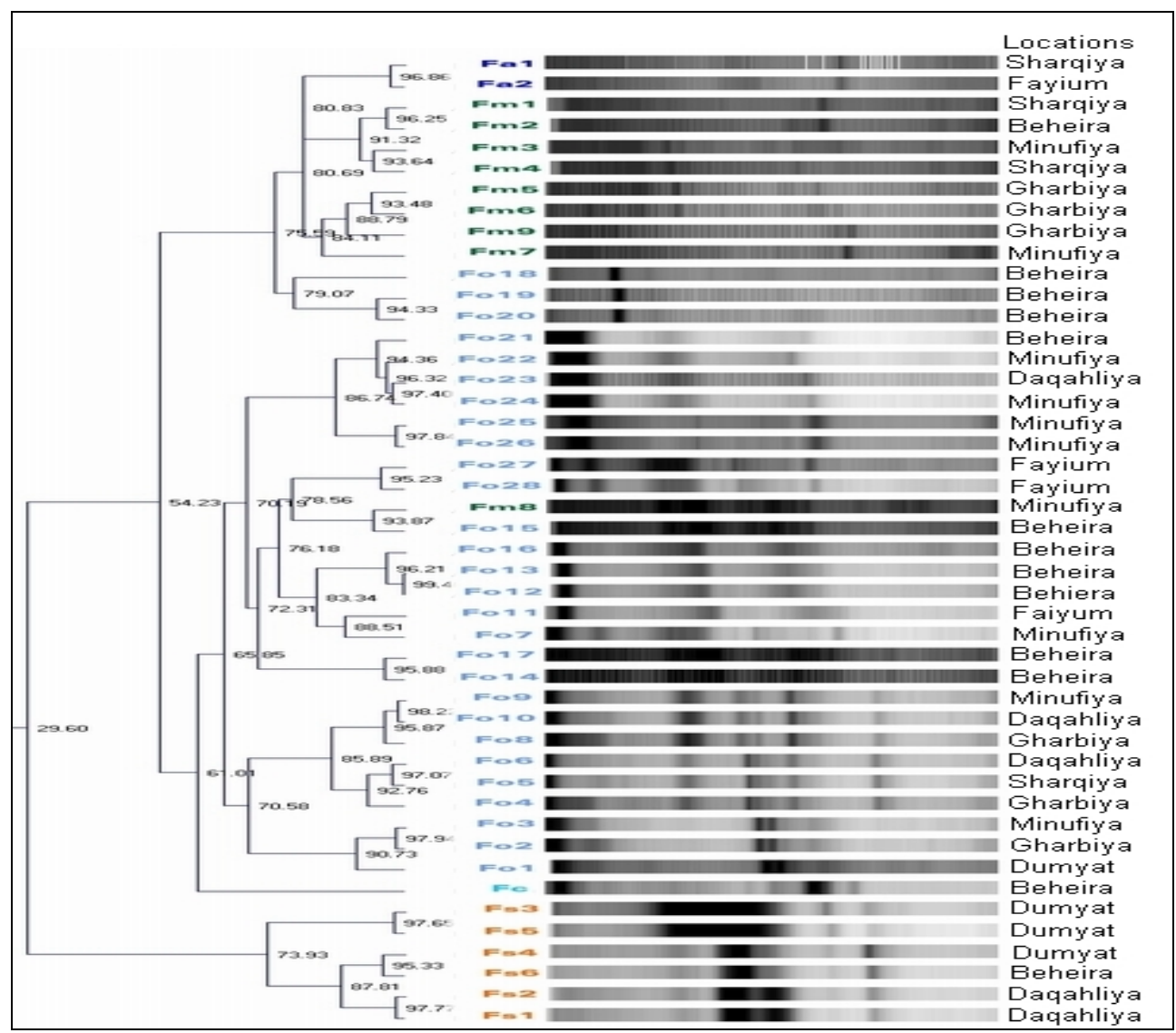

Figure 2. Dendrogram derived from the UPGMA linkage of correlation coefficients between esterase isozyme profiles from five Fusarium spp. isolates. The levels of linkage representing the Pearson product-moment correlation coefficient $(r)$ are expressed as percentages for convenience. The banding profiles against each branch represent normalized and background-subtracted digitized gel strips processed in ABB program.

isozymes to differentiate Fusarium species and four $F$. oxysporum formae specials, as well as isolates obtained from different crucifers species. On the contrary, no clearcut results were found for isozymes study of $F$. oxysporum f. sp. lycopersici recovered from different sites and different pathogenic races or vegetative compatibility groups (Elias and Schneider, 1992). SDS-PAGE is used because the method alleviates the need for culturing, and samples are analyzed in a more direct manner. This method is relatively easy and many samples can be analyzed at the same time. It is also cheaper than AFLP fingerprinting. Morever, the results obtained by SDSPAGE of whole-cell proteins can discriminate at much the same level as DNA fingerprinting (Priest and Austin, 1993) in some cases.

Cluster analysis of the protein markers data placed the Fusarium species into main groups according to their previous species assignment. The genetic similarity between Fusarium spp. isolates, similarities ranged from 21 to $54 \%$ for inter-specific and 62 to $97 \%$ for intraspecific comparisons. The application of UPGMA clustering produced two large clusters within the population. These results suggested that protein profiles data can clearly separate Fusarium spp. isolates with a few exceptions. A low correlation between protein dendrogram and geographic origin of tested isolates was found.

These results agree with those obtained by Mandeel et al. (1994) who compared SDS-PAGE patterns from eight isolates belonging to three Fusarium species. Protein profiles were distinct, and each isolate showed a uniquely characteristic profile. The data obtained from protein profiles support the potential use of this experimental approach to help distinguish between different Fusarium isolates. On the contrary, Belisario et al. (1998) found no differences when comparing total mycelium protein profiles (SDS-PAGE) of different species and formae species of $F$. oxysporum, $F$. solani and $F$. culmorum.

Isozyme analysis is frequently used for taxonomic purposes, especially when a taxon is morphologically diverse. In most cases, fungal species are easily differentiated by electrophoresis. The technique is commonly used to make recommendations on the separation or combination of species (Otrosina et al., 1992). Zambino and Harrington (1989) have also separated subspecies, varieties, and intersterility groups. 
Simple band-counting procedures can be used to distinguish taxa, although cladistic and phylogenetic information can be derived from the allelic frequencies and ratios derived from a genetic interpretation of the data. Isozyme analysis is most successful in distinguishing species and subspecies when the amount of intra-specific genetic variation is limited within a population. Esterase isozyme fingerprinting have been frequently used because of the relatively large differentiation between Fusarium spp. in contrast to other enzyme systems (Baayen, 1997).

In the present study, UPGMA cluster analysis of esterase isozyme produced two large clusters within the population, each consisting of several subclusters. Low correlation was observed between clustering in the esterase dendrogram and sampling date of tested isolates. These results suggested that esterase patterns data clearly separated Fusarium spp. isolates with a few exceptions. These results, similar to those obtained by $\mathrm{Ye}$ and $\mathrm{Wu}$ (1985) who showed that the esterase patterns are distinct for $24 \mathrm{~F}$. graminearum isolates. The patterns of 7 isolates of Gibberella zeae collected from different geographic localities appeared little different from one another and there were some identical bands of esterase isozymes in their patterns. However, no relationship was observed between isozyme patterns and geographic origin, phenotypic distance or virulence of isolates (Etebarian et al., 1996; Yli-Mattila and Hyvonen, 1996; Bosland and Williams, 1987). Also no clear-cut result was detected by malate dehydrogenase and peroxidase isozymes in discriminating between Fusarium spp. Isolates (Ye and $\mathrm{Wu}$, 1985). In summary, the genomic diversity within the genus Fusarium was determined by using esterase isozyme and SDS-PAGE and each technique could prove useful for the rapid classification of Fusarium spp. isolates.

\section{REFRENCES}

Aly AA, Hussein EM, Mostafa MA, Ismail Al (1996). Distribution, identification, and pathogenicity of Fusarium spp. isolated from some Egyptian cottons. Menofiya J. Agric. Res. 4: 819-836.

Baayen RP, van-Dreven F, Krijger MC, Waalwijk A (1997). Genetic diversity in Fusarium oxysporum f. sp. dianthi and Fusarium redolens f. sp. dianthi. Eur. J. Plant Pathol. 103:395-408.

Belisario A, Luongo L, Balmas V, Pezza L, Corazza L (1998). Fusarium wilts of winter melon. Sixth SIPaV Annual Meeting "Plant Pathology and Sustainable Agriculture" Campobasso, 17-18 September 1998 (Abst.)

Bonde MR, Peterson GL, Emmett RW, Menge JA (1991) Isozyme comparison of Septoria isolates associated with citrus in Australia and the United States. Phytopathology 81: 517-521.

Bosland PW, Williams PH (1987). An evolution of Fusarium oxysporum from crucifers based on pathogenicity, isozymes polymorphisms, vegetative compatibility, and geographic origin. Can. J. Bot. 65: 2067-2073.

Bradford MM (1976). A rapid and sensitive for the quantification of microgram quantities of protein utilizing the principle of protein dyebinding. Anal. Biochem. 72: 248-254.

Brown JKM (1996). The choice of molecular marker methods for population genetic studies of plant pathogens. New Phytologist 133:
183-195.

Colyer PD (1988). Frequency and pathogenicity of Fusarium spp. associated with seeding diseases of cotton in Louisiana. Plant Dis. 72: 400-402.

Damaj M, Jabaji-Hare SH, Charest PM (1993) Isozyme variation and genetic relatedness in binucleate Rhizoctonia species. Phytopathology 83: 864-871.

Elias KS, Schneider RW (1992). Genetic diversity within and among races and vegetative compatibility groups of Fusarium oxysporum f. $\mathrm{sp}$. lycopersici as determined by isozymes analysis. Phytopathology 82: $1421-1427$

Etebarian HR, Wilcoxson RD, Stewart EL, Woodward RP (1996). Some isozyme patterns of Fusarium culmorum. Iran. J. of Plant Pathol. 32: 9-21.

Gall C, Balesdent MH, Desthieux I, Robin P, Rouxel T (1995) Polymorphism of Tox, Leptosphaeria maculans isolates as revealed by soluble protein and isozyme electrophoresis. Mycol. Res. 99: $221-$ 229.

Hames BD (1995). One-dimensional polyacrylamide gel electrophoresis. In: Gel electrophoresis of proteins. A practical approach. Hames, B.D. and Rickwood, D. (eds.) Oxford University Press, New York 1-147 pp.

Iglesias LH Lima Simon LP (1974). Isozyme identification of zygotic and nucellar seedlings in citrus. J. Hered. 65: 81-84.

Johnson LF, JH Doyle (1986). Relationships of seeding disease of cotton to characteristics of loessial soil in Tennesse. Phytopathology 76:86-290.

Julian AM, Lucas JA (1990). Isozyme polymorphism in pathotypes of Pseudocercosporella herpotrichoides and related species from cereals. Plant Pathol. 39: 178-190.

Laemmli UK (1970) Cleaving of the structural proteins during the assembly of the head of bacteriophage T4. Nature 227: 680-685.

Majer D, Mithen R, Lewis BG, Vos P, Oliver RP (1996). The use of AFLP fingerprinting for the detection of genetic variation in fungi. Mycol. Res. 100: 1107-1111.

Mandeel QA, El-Din AYG, Mohammed SA (1994). Analysis of SDSdissociated proteins of pathogenic and nonpathogenic Fusarium species. Mycopathologia 127: 159-166.

McDonald BA, McDermott JM (1993). Population genetics of plant pathogen fungi. Bioscience 43: 311-319.

McDonald BA, Zhan J, Jarden O, Hogan K, Garton J, Pettway RE (1999). The population genetics of Mycosphaerella graminicola and Phaeosphareia nodorum. In: Lucas J. A; P. Bowyer and H. M. Anderson (eds) Septoria on cereals (pp 44-69) CAB international, Wallingford, UK.

Otrosina WJ, Chase TE, Cobb FWJ (1992). Allozyme differentiation of intersterility groups of Heterobasidion annosum isolated from conifers in western United States. Phytopathology 82: 540-545.

Petrunak DM, Christ BJ (1992) Isozyme variability in Alternaria solani and $A$. alternata. Phytopathology 82: 1343-1347.

Priest FG, Austin B (1993). Modern Bacterial Taxonomy (2nd ed.) Chapman \& Hall, London.

Rabilloud TG, Carpentier A, Tarroux P (1988). Improvement and simplification of low-background silver staining of proteins by using sodium dithionite. Electrophoresis 6: 288-291.

Snider RD (1973). Electrophoresis and taxonomy of phytopathogenic fungi. Bull. Torrey Bot. Club 100: 272-276.

Vauterin LA, Vauterin P (1992). Computer-aided objective comparison of electrophoresis patterns for grouping and identification of microorganisms. Eur. Microbiol. 1: 37-41.

Ye HZ, Wu GQ (1985). Polyacrylamide gel electrophoresis studies of the esterase patterns of Fusarium sp. causing head blight of wheat and barley. Acta Phytopathol. Sinica 15: 87-94.

Yli-Mattila T, Hyvonen J (1996). RAPD-PCR analysis of Fusarium strains - cladistic evaluation of the results. Sydowia 48: 184-195.

Zambino FJ, Harrington TC (1989). Isozyme variation within and among host-specialized varities of Leptographium vageneri. Mycologia 81: 122-128.

Zhang J, Howell CR, Starr JL. (1996). Suppression of Fusarium colonization of cotton roots and Fusarium wilt by seed treatments with Gliocladium virens and Bacillus subtilis. Biocontrol Sci. Technol. 6:175-187. 